\title{
Disciplinary power and practices of body politics: an evaluation of Dalit women in Bama's Sangati and P. Sivakami's The Grip of Change through Foucauldian discourse analysis
}

\author{
Aditya Ghosh (10 ${ }^{1 \times}$
}

Through a Foucauldian reading of Bama's Sangati (2005) and P. Sivakami's The Grip of Change (2006a, 2006b), this paper attempts to delineate the permeation and maintenance of disciplinary power in the social structure and assertion of patriarchal politics in the subjugation of Dalit female bodies. The detrimental politics of patriarchal discourse, the paper argues, degrades the existence of Dalit women, and excludes them from the equation of power relations by delimiting their access to society's productive resources and restricting their sexuality. Disciplinary power, which acts as a patriarchal tool, prescribes acceptable gestures and required behaviour, and through constant surveillance normalizes a dominant male order. It reduces Dalit women's existence into an amorphous property, readily mutilated and moulded under the whims of a phallocentric order. Discursive practices further constitute practices of body politics, making the female body an object of active site of political struggle. The paper studies Sangati and The Grip of Change as literary exemplars to demonstrate how disciplinary power, as underscored by Foucault's discourse analysis, intervenes and determines the life of Dalit women. It not only lays bare the covert body politics of patriarchy with the unfiltered depiction of women's exploitation and atrocities, but also represents a paradigm shift by advocating ways of emancipation for Dalit women.

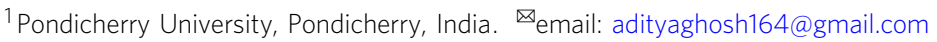




\section{Introduction}

ll oppressed, downtrodden and marginalized sections exploited through the caste system in Indian society are categorized as Dalits. Dr. Babasaheb Ambedkar thinks "caste" conflict, and not "class" problems should be held accountable for the disintegration and exploitation of Dalits in Indian society (Omvedt, 1994, p. 169). Dalit writings, which portray social oppression and marginalization of Dalits, emerged as a body of literature only in the 1960s and 1970s. In The Exercise of Freedom: An Introduction to Dalit Writing, Satyanarayana and Tharu declare: "although it is possible to identify a few Dalit writers from earlier times, the real originality and force of Dalit writing, which today comprises a substantial and growing body of work, can be traced to the decades following the late 1960 s" (2013, p. 21). Dalit writings made progress through the 1970s and 1980s, but topicality of the field gained momentum in the pan-Indian landscape with the publication of An Anthology of Dalit Literature (1992), which was edited by Mulk Raj Anand and Eleanor Zelliot, and Poisoned Bread: Translations from Modern Marathi Dalit Literature (1992) edited by Arjun Dangle.

Early Dalit writings such as Mulk Raj Anand's Untouchable (2001), which was first published in 1935, and Baburao Bagul's When I Hid my Caste (2018), first published in 1963 in Marathi, portrayed pain, anguish and exploitation of all Dalit lives, but a representation of women's sufferings was less visible in comparison to its collective resistive spirit against caste inflicted prejudices. All women face discrimination and suffer oppression in contemporary society, but the intensity of suffering compounds manifold for a Dalit woman who undergoes the triple marginalization of caste, class and gender. Renowned Tamil Dalit writer Bama describes the precarious situation of a Dalit woman: "All women in the world are second class citizens. For Dalit women, the problem is grave. Their Dalit identity gives them a different set of problems. They experience a total lack of social status; they are not even considered dignified human beings... Dalit women have to put up with triple oppression, based on class, caste and gender" (Limbale, 2010, p. 116). Eminent Dalit feminists like Sharmila Rege (2006) and Uma Chakraborty (2003) have tried to expose women's marginalization and atrocities by patriarchy recently. Concurrently, there has also been a surge of women writings from the Dalit community itself that portrays oppression and subjugation of Dalit women. This emic response has, in turn, created a miscellaneous corpus and fleshed out across a range of genres such as autobiography, memoir, poetry, short stories and novel. The Prisons we Broke (2009) by Baby Kamble, Karukku (2000) and Sangati (2005) by Bama, The Weave of my Life (2009) by Urmila Pawar, The Kaleidoscopic Story of my Life (1986) by Shantabai Kamble, Father may be an Elephant and Mother only a small Basket (2012) by Gogu Shyamala, The Grip of Change (2006a, 2006b) by P. Sivakami are some of the significant works produced by Dalit women writers. Although Dalit literature, in the initial stages, was primarily resistant literature that depicted only patriarchal atrocities and discrimination, contemporary Dalit literature by women "is chiefly an effort towards conscious construction of a casteless society based on modern liberal values. It exhibits and expresses dissent over the oppressive social structure, advocating the emancipation of Dalits and the subalterns" (Sivakami, 2017, Poetics of Political Transformation, p. 47). Bama's Sangati and Sivakami's The Grip of Change unravel the oppressive social structure and represent a paradigm shift by advocating ways of emancipation for Dalit women, and hence the focus of this paper.

As seminal to Dalit studies, both novels, Sangati and The Grip of Change, have received significant scholarly attention within Indian academia. Most scholars have primarily focussed on women's marginalization, exploitation and oppression in patriarchal social set up (Keshavamurthy, 2013-14; Sangeetha and Peruvalluthi, 2018; Vinoliya, 2018). Some others have evaluated the double oppression-for being Dalit and for being women - of women in society (Aiswariya, 2019; Masilamani and Shanthi, 2017; Raj, 2016; Soni, 2015). Yet two critical attempts stand out. Pramod K. Nayar (2011) deviates from these perspectives and investigates the hybridization of the novel form. According to him, local mythic language and narrative of folklore are transformed by Bama and Sivakami into a language of protest by the infusion of the language of rights and law. Anandita Pan (2018) also offers a different perspective by trying to construct a "Dalit woman" identity from the intersection of Dalit and gender in "Dalit Women in Mutation: The Birth of a New Social Organism". Having evaluated the body of literature available on Sangati and The Grip of Change, it is understood that there is a glaring lacuna of research work in the way in which power operates in the social structure and the role of discursive practices in the subjugation of women. This paper sets out to make this research gap a research objective to demonstrate patriarchal power as a form of disciplinary power, and the way it purports practices of body politics, making the female body an object of the active site of political struggle. Accordingly, it adopts Foucauldian concepts of disciplinary power as a framework to carry out a critical investigation of the two texts.

\section{Why Foucault?}

Many attempts have been made to define power by theorists. The Classical notion of power as domination can be traced back to Hobbes's "war on all against all" (Kavka, 1983, p. 291). Arendt (1970) considers "power corresponds to the human ability not just to act but to act in concert" (p. 44). Taking Arendt's argument forward, Pitkin (1972) suggests "that power is a somethinganything- which makes or renders somebody else to do, capable of doing something. Power is capacity, potential, ability, or wherewithal" (p. 276). Dahl (1957) offers a simple behavioural nature of power explaining that " $A$ has power over $B$ to the extent that he can get $B$ to do something that $B$ would not otherwise do" (pp. 202-203). Bachrach and Baratz (1970) elaborates on Dahl's theory further and involves power's subtle means which hinders people to put forward their own interests. According to them, $A$ succeeds in designing a socio-political culture in which " $B$ is prevented from all practical purposes, from bringing to the fore any issues that in their resolution might be seriously detrimental to A's set of preferences" (p. 7). Lukes (1974) finds these concepts of power too simplistic and postulates his own theory that power influences and determines people's interests while preventing them to realize their own purposes and needs. He states: " $A$ may exercise power over $B$ by getting him to do what he does not want to do, but he also exercises power over him by influencing, shaping or determining his very wants" (p. 23). Giddens (1984) thinks power has a "transformative capacity" (p. 15), and he further declares that "power is not necessarily linked with conflict... and power is not inherently oppressive" (p. 257). Wartenberg (1990) and Wrong (1997) characterize different forms of power, mainly power-to and power-over paradigms, and the basis on which power is exercised. Prioritizing the power-over paradigm Wartenberg states: "a theory of power has, as a first priority, the articulation of the meaning of the concept of powerover because social theory employs this concept as a primary means of conceptualizing the nature of the fundamental inequalities on society" (p. 5). MacKinnon (1987) and Butler (1990) add a gender perspective in the power as domination paradigm establishing that power relations socially construct sex/ gender discrimination. Foucault takes a radical approach and 
focusses on the construction of social organizations, the formation of individual subjectivity and the operation of disciplinary power through "hierarchized surveillance" (Foucault, 1979, Discipline and Punish, p. 177). Foucault clearly deviates from other proponents who considered "power as something that acts upon us - an outside force to which we may succumb or not but never as something that made us who we are" (Heyes, 2011, p. 160). In this regard, his "work marks a radical departure from previous modes of conceiving power and cannot be easily integrated with previous ideas, as power is diffuse rather than concentrated, embodied and enacted rather than possessed, discursive rather than purely coercive, and constitutes agents rather than being deployed by them" (Gaventa, 2003, p. 1). Having challenged the autonomous philosophical belief of the centrality and universality of sovereign power, Foucault states, "power is everywhere", and "it comes from everywhere" (Foucault, 1978, The History of Sexuality, p. 93). Moreover, contrary to other proponents, he posits that power is not always exclusionary and repressive, it has an enlightening and productive nature too. He declares: "We must cease once and for all to describe the effects of power in negative terms: it 'excludes', it 'represses', it 'censors', it 'masks', it 'conceals'. In fact, power produces; it produces reality; it produces domains of objects and rituals of truth" (Foucault, 1979, Discipline and Punish, p. 194). Foucault's radical approach to power for manoeuvring social order and manipulating an individual's behaviour through disciplinary activities makes him highly relevant and absolutely essential for this article.

The paper serves its arguments in five sections: first, it elaborates Foucault's specific deliberations on disciplinary power, docile bodies and discourse formation; second, it reads why patriarchy ensures women's exclusion from the equation of power relations, and the use of disciplinary power as a tool by patriarchy to subjugate Dalit women in the society; third, it reflects on how the female body becomes a contentious zone of de-essentializing Dalit women's right to life and property and by the gimmicks of male "protector-contract" that patriarchal Indian society upholds and discursively reinforces the stakes of domination; fourth, it looks at religious discourses and the cultural mythologies that define women in relation to their male "benefactors" and the latter's simultaneous entitlement over Dalit women; fifth, shows different possibilities by which patriarchal disciplinary power gets subverted by self-initiatives of empowerment among Dalit women and the way the two writers exert faith in the consciousness yielding strengths of education.

Disciplinary power, docile body and discourse. Foucault notices a disruption in the way sovereign power operated and a radical shift away from it in the way modern power operates. Sovereign power relied on the public spectacle of the annihilation of the deviant body "to reassert and reinforce the sovereign's absolute authority" (Havis, 2014, p. 111). Sovereign power was "essentially a right of seizure: of things, time, bodies, and ultimately life itself; it culminated in the privilege to seize hold of life in order to suppress it" (Foucault, 1978, The History of Sexuality, p. 136). On the other hand, there has been a significant reduction of corporal punishments, and a gradual rise of structural and regimented regulation of bodies to ensure submissiveness and compliance of subjects in modern societies. This process of subjugating people through "an uninterrupted, constant coercion" for ensuring "the meticulous control of the operations of the body" is generally perceived as "disciplines" (Foucault, 1979, Discipline and Punish, p. 137). In contrast to the sovereign power, disciplinary power maintains invisibility in its operation, while subjecting bodies "to a continual process of surveillance, examination, judgment, and correction" (Havis, 2014, p. 111). Having moved away steadily from earlier barbaric methods of bodily infliction and cults of mirror punishment does not mean the perpetrator is exempted from being reprimanded and allowed to go scot-free. On the contrary, punishment became less grotesque and more severe, resulting in the production of "subjected and practiced bodies" (Foucault, 1979, Discipline and Punish, p. 138) by absolute deterrence of the body's power to retaliate. Disciplinary power places more emphasis on keeping subjects under surveillance and administering constant mental discomfort as a new mode of excommunication. Foucault explains the working of this phenomena through visualizing a situation where a systemic flow of "obstacle-signs" is maintained which, at any given time, dispenses its function by upholding unarbitariness, transparency and justifiability (Foucault, 1979, Discipline and Punish, pp. 104-105). Furthermore, by inducing fear, shame and a sense of propriety, the invisible power of disciplining force gains acceptance as an institutional and security enforcement apparatus. When any transgressive action or body disturbs such an order of discipline, comes under the vigilance of the social and collective values of the public, who have pedestalled this invisible power into a form of institution. Herein, Foucault notes, the invisible power gets actuated on the premises of being perceived as "the lesson, the discourse, the decipherable sign, the representation of public morality" (Foucault, 1979, Discipline and Punish, p. 110). The aim is to render the body as an automaton of the disciplinary machine, and in this way, Power transforms into policing and reforming as well as in producing docile bodies.

A docile body constructed through the operation of disciplinary power is compelled to be "obedient in order to be managed" and is moulded into "a subject who is self-monitoring... useful, productive" (Heyes, 2011, p. 162). "More is required of the body now than mere political allegiance or the appropriation of the products of its labour: the new discipline invades the body and seeks to regulate its very forces and its operations, the economy and efficiency of its movements" (Bartky, 1997, p. 129). Foucault discusses three techniques-hierarchical observation, normalizing judgment and examination-which train individuals into the formation of docile bodies (Foucault, 1979, Discipline and Punish, pp. 170-194). Contrary to the direct use of violence, the anxiety of anonymous vigilance and fear of reproach is induced into the subject's psyche through these techniques; and it guarantees the continuity of the submissive act through means of selfadministration and self-correction. Hierarchical observation bestows power the sense of ubiquity, and subjects become more concerned, calculative and organized under the apprehension of being under constant surveillance. Normalizing judgement involves ways in which certain norms and practices are standardized in the social structure over a period of time. It is "enacted through the micromanagement of behaviour in areas of social life" (Heyes, 2011, p. 163). Examination, the third technique, is the culmination of the process of embedding a normalizing gaze. "The examination is a ritualized means by which each individual is subjected to a disciplinary gaze, compared against the norm, ranked, classified, and ultimately reformed toward the norm" (Havis, 2014, p. 114).

By defining compliant behaviours and legitimized notions, disciplinary power constitutes a body of knowledge that outlines normal and appropriate behaviour for individuals. This body of knowledge or discourse acts as an important apparatus in the subordination of subjects by disseminating approved behavioural codes through various social institutions. Discourse not only normalizes certain rules and practices for the effective functioning of power that authority wants to assert but it also intends to negate and subvert any alternative interpretations with the ability to challenge the established order by constituting a parallel meaning. "In every society, the production of discourse is at once 
controlled, selected, organized and redistributed by a certain number of procedures whose role is to ward off its powers and dangers, to gain mastery over its chance events, to evade its ponderous, formidable materiality" (Foucault, 1981, The Order of Discourse, p. 52). Effective operation of disciplinary power through discourse produces bodies that are "manipulated, shaped, trained, which obeys, responds, becomes skilful and increases its forces" (Foucault, 1979, Discipline and Punish, p. 136). Thus, the docile body is malleable, subservient and a receptive vessel of supervision. It can exercise its utility power by becoming a medium of disseminating the discourse of discipline and control through persistently verifying and preserving the morale of a lawabiding entity. In doing so, the docile body enters the realm of the political and every day, and participates with disciplinary power to construct the system of hierarchy and domination in the social structure.

Disciplinary power: patriarchal tool of woman's subjugation. Patriarchy is defined by Heidi Hartmann as "... a set of social relations which has a material base and in which there are hierarchical relations between men and solidarity among them which enable them in turn to dominate women" (Hartmann, 1979, p. 14). Here, the phrases "material base", and "solidarity among them" which refers to men, have profound significance in the assertion and maintenance of patriarchal power in the society. Material base extrapolates that there is an economic dimension to patriarchy. Patriarchy wants to control the economic base of the society by subordinating women and exploiting their labour force. This aspect of patriarchy is explicitly depicted in Sangati and The Grip of Change. Bama's personal account in Sangati is a historical document of the exploitation of the physical labour of women. She writes: "we have to labour in the fields as hard as men do, and then on the top of that, struggle to bear our children. As for the men, their work ends when they've finished in the fields" (Bama, 2005, pp. 6-7). Although they work as hard as a man, they are not paid as a man gets paid; and it enrages Bama: "the women, in any case, whatever the work they were paid less than the men" (Bama, 2005, p. 18). Kathamuthu in The Grip of Change abuses and orders his first wife Kanagavalli, "Are you here to pass the judgement early in the morning? Go inside and get some coffee. Now!" (Sivakami, 2006a, p. 7) when she tries to interfere in the matter of Thangam. Women are exploited of their physical labours inside the house as well as in workplaces.

Hartmann's argument around solidarity among men is noticed in restricting women's sexuality. Women's sexuality is stringently regulated and disciplined by patriarchy. A boy is permitted to marry outside his caste but a girl is not, and Bama disturbingly narrates: "if a girl marries outside the caste no one will accept it. They all make a big quarrel out of it" (Bama, 2005, p. 106). Her vivid portrayal of Essakki's murder by her brothers for marrying a boy from another caste (Bama, 2005, p. 53), and the account of a girl being "beaten up in the house every day by her father and her brothers" (Bama, 2005, p. 106) for having fallen in love with a Palla caste boy are disturbing documents of humiliation, cruelty and mortification of women for not adhering to patriarchal codes. "Whatever happens must be according to their pleasure and convenience. If anything is ever arranged for a woman's convenience, they will never stand for it. They will leap between heaven and earth to prevent it" (Bama, 2005, p. 110). This statement of Bama reflects the patriarchal social setup's tendency to dominate all spheres of women's life.

Disciplinary power ensures women's exclusion from the equation of power relations by denying "access to some essential productive resources and by restricting women's sexuality" (Hartmann, 1979, p. 14). Disciplinary power circulates "in a network of relations" (Foucault, 1979, Discipline and Punish, p. 176) in the social structure for the maintenance of "hierarchized surveillance" (Foucault, 1979, Discipline and Punish, p. 177). The hierarchized surveillance is highly relevant in the context of social power in Indian society. Since there is a hierarchy based on caste, everyone comes under surveillance in hierarchical order, and women face the worst predicament of this disciplinary power. Patriarchy collectively or rather in solidarity maintains "its economic hold over its female subjects" (Millett, 1970, p. 39) by subjugating women through hierarchized surveillance.

Woman's identity is denigrated in society, and she is indoctrinated to be inferior and subservient through a "normalizing process" (Foucault, 1979, Discipline and Punish p. 184). This normalizing process starts very early in a subject's life; and with calculative measures "its behaviour", and "its gestures" (Foucault, 1979, Discipline and Punish, p. 138) are disciplined. "If a boy baby cries, he is instantly picked up and given milk. It is not so with the girls" (Bama, 2005, p. 7). Moreover, "boys are given more respect. They'll eat as much as they wish and run off to play. As for the girls, they must stay at home and keep on working all the time..." (Bama, 2005, p. 7). Bama, in Sangati, makes it apparent that young girls are compelled to comply with "required behaviour" (Foucault, 1979, Discipline and Punish, p. 166) prescribed by patriarchy as they are not permitted to take part in games like kabaddi and marbles since these are considered to be boy's games. The required behaviour also coerces them to adopt feminine roles and be busy with "cleaning vessels, drawing water, sweeping the house, gathering firewood, washing clothes, and so on" (Bama, 2005, p. 7).

Disciplinary power also "prescribes movements" (Foucault, 1979, Discipline and Punish, p. 167) for subjects, and surveillance makes sure it is strictly followed. Gowri, in Sivakami's The Grip of Change, is scolded by her father Kathamuthu every time she sits with elders and listens to them as this is not prescribed by patriarchy for a young girl. When she fails to understand Kathamuthu's prescribed order she is immediately apprehended with a barrage of abuses, "You lazy girl! What are you staring at? Run and get pen and paper" (Sivakami, 2006a, p. 9). The incident emphasizes the kind of training women are given from a very early age to adhere to prescribed movements by patriarchy. Bama depicts a true picture of women growing up with required behaviour and prescribed movements: "We aren't allowed to talk loudly or laugh noisily; even when we sleep we can't stretch out on our backs or lie face down on our bellies. We always have to walk with our heads bow down, gazing at our toes" (Bama, 2000, p. 29).

Surveillance on women is not only maintained by male counterparts but also by fellow female subjects. Disciplinary power is an administering master gaze, and it has a capacity to replicate a similar genetic carrier in women's psyche to appropriate and enact the same male gaze. The purpose of this transference of the male gaze is to induce "a state of conscious and permanent visibility that assures the automatic functioning of power" (Foucault, 1979, Discipline and Punish, p. 201). This "state of conscious and permanent visibility" evokes fear and anxiety in the minds of the subjects, and "confused penalty" (Foucault, 1979, Discipline and Punish, p. 257) petrifies them for not conforming to the conventions and rituals. Women's appropriation of male ideology and its contribution to the woe of other women is represented in Sivakami's The Grip of Change. When Thangam is raped by Paranjothi Udayar, instead of sympathizing with her and giving her moral support, Kamalam, who is Paranjothi Udayar's wife, makes all arrangements to further humiliate and degrade her. Thangam is dragged out of her house, flogged and beaten up. Kamalam is not the only woman who causes great 
distress to Thangam in the novel. Having taken cognizance of the rumour associating Thangam and Paranjothi, and the atrocities inflicted on Thangam, Valliammai, sister-in-law of Thangam, does not intend to extend her helping hand, she instead vilifies Thangam;

They beat her up. Good! Why did they leave her alive? That whore thinks too much of herself. She thinks that she's very beautiful. That's why she went after that Udayar. When she loses her shape, he'll throw her out, and she'll be in a state worse than a dog's. (Sivakami, 2006b, p. 28)

Another woman, Lalitha, picks a fight with Elango. They engage themselves in a conversation that revolves around the tension that is going on in the novel, and Lalitha accuses Thangam by calling her a whore: "Are you talking in support of that whore?" (Sivakami, 2006b, p. 56). Having reminded of the role of Paranjothi in Thangam's rape she further adds, "He is a man! He can do anything that pleases him" (Sivakami, 2006b, p. 56). Both Valliammai and Lalitha incorporate male precepts accurately and become patriarchy's interpellated representatives. They mortify Thangam and push her to a more deplorable condition. Their complete annihilation of the reputation of Thangam strengthens the root of phallocentric power and confirms the successful installation of the male gaze into the female psyche.

Discursive construction of the Body as a site of political struggle. "The body is a social construction" (Holdrege, 1998, p. 343 ), and it is constructed over a period of time through discursive practices. Michel Foucault's social theories promulgate the means through which disciplinary techniques of power regulate and control individuals, and produce docile bodies. Construction of the body through discourse is reflected in works of feminist critics too, as Julia Kristeva, Luce Irigaray, Helene Cixous focuses "on the role of discourse in constructing the female body, emphasizing that the body is a text inscribed by the structures of language and signification and hence there is no experience of the body apart from discourse" (Holdrege, 1998, p. 344). Sivakami's novel The Grip of Change demonstrates that "the female body is a site of political struggle" (Holdrege, 1998, p. 345). The story revolves around Thangam, who is a childless young widow, in the patriarchal social set up. Her in-laws have thrown her out of the house after the death of her husband. There is a larger politics behind her eviction, and in order to expose patriarchy's covert politics the paper brings the analogy of sati into the discussion from Gayatri Spivak's essay Can the Subaltern Speak? (1988). In the ritual of sati women had to ascend the pyre of the dead husband and self-immolate. It has to be remembered that sati was prevalent in erstwhile Bengal where women could inherit the dead husband's property. Therefore, this inhuman evil custom was strictly enforced by patriarchy for the acquisition of a dead husband's property bypassing the wife. Spivak quotes P.V. Kane, a great historian of Dharmasastra; "In Bengal, [the fact that] the widow of a sonless member even in a joint Hindu family is entitled to practically the same rights over joint family property which her deceased husband would have had... must have frequently induced the surviving members to get rid of the widow by appealing at a most distressing hour to her devotion to and love for her husband" (Spivak, 1988, p. 300). Therefore, patriarchy's material basis is apparent in the perpetuation of the ritual. Similarly, in The Grip of Change Thangam's eviction from the house by her husband's brothers after the death of her husband has a material basis. She is driven away from the family by her inlaws for hidden intention to seize the share of property she is entitled to inherit. Her grievance to Kathamuthu makes it clear:
"My husband's brothers tried to force me, but I never gave in. They wouldn't give me my husband's land, but wanted me to be a whore for them! I wouldn't give in" (Sivakami, 2017, pp. 6-7).

Sati needs more elaboration for the comprehension of larger politics and the construction of a woman's body as a site of political struggle in The Grip of Change. Indian patriarchal society and British colonial rule got into a serious confrontation regarding the perpetuation of this traditional ritual. On the one hand, Indian society was not willing to loosen the grip of domination and was hell-bent on establishing the discourse of 'reward' for women for the sacrifice on holy fire. On the other hand, British imperial power took the route of justifying their 'social mission' as part of their larger mission of civilizing the world and bringing light to Indian society by eradicating dark practices. The whole confrontation took the form of an ideological conflict between two power relations to gain hegemonic control. Both hegemonic powers took up woman's bodies to justify their welfare programs. To give a fundamental consolidated view, the Indian patriarchal system rejected the British reformist idea of eradicating sati, but they opposed the idea of reform in disguise of protecting the rights of good and loyal women who want to self-immolate in their husband's pyre. On the other hand, British imperial rule wanted to abolish sati to save women and liberate them from the clutches of the oppressive Indian patriarchal social system but, they did it with a hidden intention of establishing hegemonic control by undermining the Indian social system. What is noteworthy is that although two hegemonic power relations fought tooth and nail for the rights and welfare of women, women's representation and opinions are nowhere to be found regarding the issue. In reality, woman's cause was not the real issue. The body of a woman was politicized and used in a larger political struggle.

Now, we turn our attention to The Grip of Change and locate Thangam in this framework of body politics. The novel starts by depicting the distressing and disturbing condition of Thangam. She is thrown out of the house by her in-laws. Later, her landlord Paranjothi Udayar rapes her in a secluded area. Finally, she is mercilessly beaten up by Kamalam's men for two reasons-on the accusation of getting sexually involved with Paranjothi Udayar and for coming close to the upper-caste locality. Having been subjected to all these atrocities, Thangam comes to Kathamuthu in anticipation of getting justice. Kathamuthu takes up the case and consoles Thangam promising to deliver justice by making the upper caste perpetrators feel sorry for their misdeeds. But as the story progresses it is realized that what started with promising to deliver justice for Thangam, actually transpired to be a large-scale caste conflict. Kathamuthu takes up the issue of Thangam and uses it as a ladder to go up the order in politics. He changes the story in the petition against the perpetrators and makes it a caste issue to suit his own agenda. When Thangam stresses her issue, Kathamuthu barks at her: "I've changed the whole story. Don't you understand? Now don't screw it up. If you say anything different from what's written in the petition, you'll be jailed. Understand?" (Sivakami, 2017, ch. 1). He fulfils his own political ambition by making Thangam's violated body a site of political struggle against the upper caste community. Although he makes them pay a penalty for their atrocities on Thangam, he pockets a large amount of the money by manipulating her. On the other hand, upper-caste men accept Thangam's violation of honour and agree to pay for her well-being. But they agree because of extreme national pressure, not out of genuine concern for Thangam. Although both parties manage to reach a consensus keeping Thangam's cause in front of them, in reality, her issue gets relegated to the background. Thangam's body is only used as a weapon for the political struggle between two hierarchical power relations to gain hegemonic control over the other. 
Role of religious discourse in shaping the practices of body politics. Religion and Indian society are inseparable, and religious scriptures such as the Vedas, Puranas, Mahabharata, Ramayana play a significant part in the construction of a socio-cultural discourse that determines manners, morality and ethics of individuals. In The Grip of Change Kathamuthu is seen constantly hoodwinking illiterate fellow villagers by extensively reciting from Mahabharata and Ramayana (Sivakami, 2006a, p. 33). Religious discourse preaches that there is an afterlife, and based on their karma individuals are rewarded or punished. Austin B. Creel in Dharma in Hindu Ethics states: "By doing good karma, one may move towards a higher plane of existence and this way progress towards Moksa or ultimate freedom. Within the prescribed patterns of one's dharma, which is theoretically founded on one's present achievement or one's actual nature, one can attain a higher future or new Dharma in future incarnations" (Creel, 1977, p. 4). Sadanand Paswan in Dalits and Practices of Untouchability expresses his anger for the role of religious scriptures for marginalization and oppression of women. He writes: "The root cause of suffering for women in India are these so-called Hindu religious books... According to Manusmriti, women have no right to education, independence, or wealth. It not only justifies the treatment of Dalit women as sex objects... but also justifies a number of violent atrocities on women" (Paswan, 2011, p. 182). All important social institutions in Indian society are replete with religious discourses. Religious belief of women in Sangati is reflected in the narrator's mother's statement about marriage: "Haven't you heard the words the priest speaks at the time of the tali-tying?... He says 'What God puts together, let no man put asunder... We have to live our lives according to the promise we made to God, in front of four, five people" (Bama, 2005, p. 94).

Patriarchy makes the influence of religious discourse its advantage to manoeuvre social practices to subjugate women. Woman's everyday life is disciplined by drawing on mythological stories in Hindu epics, and that is why women in The Grip of Change and Sangati are needed to be examined with an evaluation of two important episodes from MahabharataDraupadi's marriage, which is otherwise known as swayamvara, and disrobing of Draupadi- and the fate of Ahalya from Ramayana. In the case of Draupadi's marriage, she was not loved and wedded; she was given as a prize in a swayamvara (a practice in which a woman chose her husband from a list of candidates) to the most skilful archer who happened to be Arjun. In another Hindu epic Ramayana, Lord Rama proved he was the strongest man by breaking a historical bow which other men, who were present, could not, thereby winning Sita as a prize. Those legendary women in epics Mahabharata and Ramayana were considered to be the most beautiful women in the world; and men, who would want to marry them, had to prove that they were the best among other contenders. There is an underlying cultural process of the formation of female subjectivity, and the construction of a hysteric collective fantasy around women in this ritual of swayamvara. Constitution of "hyperbolic admiration" (Spivak, 1988, p. 297) of woman evoked a strong desire among men to win the most beautiful woman or rather, the prized subject. Rational inference generates a strong feeling that women were given utmost importance, and it was a woman's free choice to choose who she was going to marry in swayamvara. Constitution of feminine free will here is actually a "displaced place of the female subject" (Spivak, 1988, p. 300) since there is an involvement of paradox with the narrative of woman's freedom of choice. Construction of a narrative of granting women freedom of choice, and the constitution of hyperbolic admiration and a hysteric collective fantasy around women is a patriarchal strategy to normalize woman's consciousness with the euphoria of being desired, possessed and protected. Here woman's consciousness is carefully manipulated to understand the paradoxical freedom of choice "as an exceptional signifier of her own desire" (Spivak, 1988 , p. 300). Fathers of women took great pride in the sparkling beauty of their daughters and wanted to make sure the object of his pride went to someone great, very often the greatest warrior, therefore, is protected for the rest of her life. For men, the felicity of winning over the most prized subject confirmed their status as great. Husbands became the subject of envy to other men for taking possession and being the protector of the most desired body. Woman, the Subject, remained as a mere body and became the object of transference in changing custodianship from father to husband, from one male protector to another. Both father and husband-representatives of patriarchy-are successful to prove their worth and superiority using the female body.

The female body as an object of protection in the greater scheme of patriarchal politics is represented in the select texts. In The Grip of Change Kathamuthu's second wife, Nagamani belonged to the upper caste, but Kathamuthu married her when Nagamani became a widow. Kathamuthu takes extra credit for this and tries to prove himself a great person in front of Thangam: "I'm living with this woman who doesn't belong to our community. She's upper caste. She was a struggling widow, so I provided her a safe haven... And she now lives like a queen. I'm a man with some say in the community..." (Sivakami, 2006a, p. 10). Whenever Nagamani tries to voice her opinion by interrupting Kathamuthu, he humiliates her with reference to her past: "Shut your mouth! Nobody cared for you till I took you into my house" (Sivakami, 2006a, p. 9). Kathamuthu takes pride in the fact that he has protected Nagamani, and shoots an indicator to Thangam that he would be her protector too. Patriarchal social set up has normalized with an effective discourse that men are the protector of women, and women are an object which is to be protected and possessed. In Bama's Sangati, Periamma, Anantama (p. 30), Thaaye (p. 42) are all beaten up regularly by their husbands. But they do not protest because of patriarchal indoctrination that men are their protector, therefore, the act of violence by them is justified. When men are confronted for the violence against women, they would justify their act by saying "She is my wife" (Bama, 2005, p. 42). Women are reduced to an object which men possess like any other inanimate object.

The shamed, humiliated and disgraced body of Thangam becomes the object of protection for men multiple times in The Grip of Change. Thangam's case (she is degraded by men and saved by other men repeatedly) offers intertextual references to Draupadi in the Mahabharata and Ahalya in Ramayana. Draupadi's humiliation of being disrobed was caused by Yudhistir's mistake because he placed Draupadi as a bet in a game of dice and lost. Krishna, a male friend of Draupadi, came to save her from the humiliation. On the Other hand, Lord Indra disgraced Ahalya by raping her in disguise of her husband. Ahalya had to suffer the consequences by turning into a stone as she was cursed by her husband, and her fate was finally reversed by Lord Rama. In both cases, a male folly leaves a female body vulnerable to be humiliated only to be saved by a male sympathizer. In the case of Thangam, her in-laws, who are men, degrade her and leave her in a dire situation. Paranjothi Udayar turns into her saviour by providing work in his lands. A few days later, he rapes Thangam. She is humiliated and becomes an object which is to be protected again. This time she is saved by Kathamuthu- a different saviour but male nonetheless. In the end, Kathamuthu, who promised to deliver justice for her, also attempts to sexually exploit her. In all cases, Thangam's body is used by patriarchy to achieve personal gain and satisfaction. Her in-laws attempt to sexually exploit her, throw her out of the house and seize her share of the property; Paranjothi Udayar sexually 
exploits her body; and Kathamuthu fulfils his political ambition and wants to satisfy his sexual desire by exploiting Thangam's body. Turning into a saviour was just a patriarchal strategy to justify the image of protector for these men.

Empowerment through education: means of resistance to oppressive power. "Discourse" Foucault affirms, "can be both an instrument and an effect of power, but also a hindrance, a stumbling block, a point of resistance and a starting point for an opposing strategy. Discourse transmits and produces power; it reinforces it but also undermines it and exposes it, renders it fragile and makes it possible to thwart it" (Foucault, 1978, The History of Sexuality, p. 101). But, Nancy Fraser (1989) and Nancy Hartsock (1990) find limitations and problematize Foucault's proclamation of the productive paradigm of power. They place this claim with Foucault's argument about individual's reduction to mere docile bodies by the operation of disciplinary power rather than subjects with the ability to form a resistance against power. They assert that if individuals are perpetually repressed and reduced to docile bodies then it is not clear who resists power and how this resistance takes shape. According to Fraser and Hartsock, Foucault has failed to offer any neutral normative solutions and adequate resources that would enable to counter the structures of domination and usher in a social change. A discussion of the issues raised by Fraser and Hartsock can be found in Foucault's later works. Foucault states: "there are no relations of power without resistances; the latter are all the more real and effective because they are formed right at the point where relations of power are exercised" (Foucault, 1980, Powers and Strategies, p. 142). Foucault remained firm in his position that power relations construct individual subjectivity, and power structure limits the subject's autonomy and freedom. But, he offers an indication that individuals can resist the effects of normalization (Sawicki, 1998, p. 105) by deciphering and problematizing the processes of subject formation, and constructing alternative avenues that "can produce sites of contestation over the meanings and contours of identity, and over the ways in which certain practices are mobilized" (Lloyd, 1988, p. 250). Foucault introduces his view of freedom from domination in his work on ethics (1988) but rules out the complete liberation of an individual from the power structure of the society. He suggests that power relations need to be cautiously challenged in more specific, localized areas and prudently manipulated to counter oppression as "reversing power positions without altering relations of power is rarely liberating" (Sawicki, 1998, p. 102). He places emphasis on the significance of constructing alternative cultural norms, and the formation of new attitudes and behaviours for the empowerment of oppressed individuals.

Personal and semi-personal documentations of patriarchal oppression by Dalit women writers Bama, P. Sivakami and others are actually taking shape as a body of literature that aims to construct a counter-discourse by raising awareness in the Dalit community. The accounts of these writers not only lay bare the covert body politics of patriarchal power with the unfiltered depiction of women's submission, exploitation and oppression but also, outline the road to emancipation from the clutches of patriarchy through proper awareness and effective education. Restoration of confidence and resurrection of identity is possible only by fostering hope, raising awareness through education about civil rights, and inculcating a consciousness about exclusionary politics of patriarchy. Bama's emphasis on education is reflected in Abedi's statement: "Bama through her writing hopes to influence Dalit women readers to shape their lives positively. Her work lay a lot of emphasis on the empowerment of Dalits through education" (Abedi, 2010, p. 109). Both Bama and
Sivakami in their novels Sangati and the Grip of Change have focussed on patriarchy's instruments, which are institutionalization of marriage and construction of ideal motherhood, that are used to subordinate women.

The foundation of marriage is strongly built upon the wife's domestic subjugation and concealed slavery. In this institution of marriage, characteristics of a "true woman" (Chaudhury, 2011, p. 4) are normalized and ideal motherhood is constructed by discursive practices. Kate Millett admonishes marriage by claiming it is "a means of emotional manipulation" (Millett, 1970, p. 37), and marriage and motherhood are romanticized to hide the oppression and subordination of women (Millett, 1970, p. 35). Sangati and The Grip of Change are literary exemplars in which exploitation in marriage and oppression of mothers are demonstrated. Bama, in her childhood, had seen the atrocities her grandmother and other women like Thaayi, Mariamma, Anantama, Essakki, Rakkamma, Periamma had to endure and still, they had to be forgiving, provide relentless service and fulfil their role as wife and mother in the family. On the other hand, Gowri in The Grip of Change has seen Kanagavalli and Nagamani are always abused and coerced to adopt the servile attitude and be busy nurturing children. Sometimes Kathamuthu "hit Nagamani so hard that she had to lie for days together, unable to eat or drink" (Sivakami, 2017, p. 93). Therefore, she is frightened at the prospect of marriage. Sivakami portrays Gowri's inner feelings, "Gowri was quite nervous... Scenes of her marriage ceremony began to float in her dreams... fear of marriage remained. She hated the idea of it" (Sivakami, 2017, p. 94).

Drawing on Foucault's suggestion offered in his work on ethics about carefully shifting domination of power by self-practicing of freedom and constructing a counter-discourse, both Bama and Sivakami considers education and awareness are primary tools to resist patriarchal tools of domination. Bama laments the lack of education for women in the Dalit community: "because we haven't been to school or learned anything, we go about like slaves all our lives from the day we are born till the day we die. As if we are blind, even though we have eyes" (Sangati: Bama, 2005, p. 118). On the other hand, Gowri embodies the change in attitude in the new generation of Dalit women in The Grip of Change. Watching the plight of Thangam, Gowri mentally drifts, recognizes her conflicted reality, the states of women's abjection and patriarchal control. Sivakami describes Gowri's inner thought;

'I belong to the same caste as that woman. How can I be sure that I won't be beaten black and blue like her? I have seen things like this happening in cinema. This is real, terror is sleeping on a mat in my house.' She felt revulsion for the society where such things could happen. (Sivakami, 2017, p. 14)

Gowri refuses to be entrapped within the institution of marriage and be subjected to the patriarchal construct of ideal motherhood. She is aware, and her empowered consciousness constitutes a counter-discourse to subvert the dominant discourse of patriarchy. Gowri rejects marriage and exclaims: "The sufferings that my mother underwent in her marriage! I don't want to be tortured like her by some man" (Sivakami, 2017, p. 124). Her refusal goes further than just rejection of marriage, "It is the refusal of the economic, ideological, and political power of a man" (Wittig, 1993, p. 105).

\section{Conclusion}

Through Bama's Sangati and Sivakami's The Grip of Change, the paper demonstrates how power, as underscored by Foucault's formulation of disciplinary power and discourse analysis, 
intervenes and determines the life of Dalit women. These texts become a collective voice in the articulation of pain and sorrow of the oppressed, marginalized women who are at the mercy of power and victims of body politics which are instrumental to the sustenance of patriarchy. The paper argues, through a Foucauldian analysis of the operation of disciplinary power and maintenance of effective discourse, the ways in which patriarchal structures exert power, perpetuate gender injustices and muffle resistive voices through the internal machination of social control and ritualized conduct. Individual Dalit women at the interface between domestic and public/collective fold are coerced into replaying norms, first set by their immediate male counterparts, then monitored by matriarchs and co-women within their community and then from the higher mainstream which prescribes a delimiting socio-moral boundary sanctioned by an existing abrasive and older cultural genealogy. This triangulation of adherence, accountability (on the basis of reward in the form of societal acceptance and punishment in the form of violent ostracization) and repetitive operability of disciplinary order loops into multiple discursive fields that anchor its power by maintaining continuity through a queasy subjection to benign, and more often malign, ways of obedience. The superstructure of disciplinary power is primal and replicates through a synchronous internalization of everyday rituals and taboos: with the first, governing the order of normal, and the second, warning the order of deviance. That Dalit community and in particular, Dalit women had and have been historically entangled with this form of stigmatic and regressive order is only more re-narrativized than resolved, Bama and Sivakami had realized in the conception of their art. If their remedial prism within their text was to envision a cautious pedagogy on how disciplinary power operates invisibly; it was also devised for calling out its predatory nature and making strategic fissures to fight out from its belly. Such an armament indeed, as the writers champion, lay on the equalizing power of education and its dispelling of unquestionable obedience. This power from and of education is the self-caring technology of power, an emancipatory disciplining which Foucault counts positive and forward-gearing and one echoing the aspirational worldview of both Bama and Sivakami. Thus, coming full circle, the paper has attempted to acknowledge Foucault's increasing relevance in the analysis of Dalit literature and in the workings of forced status imposition on the vulnerable and yet reclaiming voices of Dalit women.

Received: 18 March 2020; Accepted: 14 April 2021;

Published online: 27 July 2021

\section{References}

Abedi Z (2010) Contemporary Dalit literature: quest for Dalit liberation. Arise Publishers and Distributors

Aiswariya G (2019) Being a woman and a Dalit: a study of Sivakami's The Grip of Change. J Gujarat Res Soc 21(10):164-167

Anand MR, Elenor Zelliot E (eds) (1992) An anthology of Dalit literature. South Asia Books

Anand MR (2001) Untouchable. Penguin Books

Arendt H (1970) On violence. Harcourt Brace

Bachrach P, Baratz M (1970) Power and poverty, theory and practice. Oxford University Press

Bagul B (2018) When I hid my caste (trans: Pinto J). Speaking Tigers

Bama (2000) Karukku (trans: Holmstrom L). Oxford University Press

Bama (2005) Sangati (trans: Holmstrom L). Oxford University Press

Bartky SL (1997) Foucault, femininity and the modernization of patriarchal power. In: Conboy K, Medina N, Stanbury S (eds) Writing on the body: female embodiment and feminist theory. Columbia University Press, pp. 129-154 Butler J (1990) Gender trouble: feminism and the subversion of identity. Routledge Chakravarti U (2003) Gendering caste: through a feminist lens. Bhatkal \& Son
Chaudhury S (2011) Devi/Rakshashi: representations of women in Bengali Rupkatha. In: Chaudhury S (ed) Shifting identity: constructions and reconstructions of the feminine in Indian Literatures. Books Way, pp. 1-16

Creel AB (1977) Dharma in Hindu ethics. Firma KLM Private Ltd.

Dahl RA (1957) The concept of power. Syst Res Behav Sci 2(3):201-215

Dangle A (ed) (1992) Poisoned bread: translations from modern Marathi Dalit literature. Orient Longman

Foucault M (1979) Discipline and punish: the birth of the prison (trans: Sheridan A). Vintage Books

Foucault M (1980) Powers and strategies. In: Gordon C (ed) Michel Foucault: power/knowledge. Harvester Press

Foucault M (1988) The ethic of care for the self as a practice of freedom. In: Bernhauer J, Rasmussen D (eds) The final Foucault. MIT Press

Foucault M (1978) The history of sexuality, vol 1, an introduction (trans: Hurley R). Random House

Foucault M (1981) The order of discourse. In: edited and introduced by Robert Young. Untying the text: a post-structuralist reader. Routledge \& Kegan Paul, pp. $51-78$

Fraser N (1989) Unruly practices: power, discourse and gender in contemporary social theory. Polity Press

Gaventa J (2003) Power after Lukes: a review of the literature. Institute of Development Studies

Giddens A (1984) The constitution of society: outline of the theory of structuration. Polity Press

Hartmann HI (1979) The unhappy marriage of Marxism and feminism: towards a more progressive union. Cap Class 12(2):1-33

Hartsock N (1990) Foucault on power: a theory for women? In: Nicholson L (ed) Feminism/postmodernism. Routledge

Havis DN (2014) Discipline. In: Lawlor L, Nale J (eds) The Cambridge Foucault Lexicon. Cambridge University Press, pp. 110-119

Heyes CJ (2011) Subjectivity and power. In: Taylor D (ed) Michel Foucault: key concepts. Acumen, pp. 159-172

Holdrege BA (1998) Body connections: Hindu discourses of the body and the study of religion. Int J Hindu Stud 2(3):341-386

Kamble B (2009) The prisons we broke (trans: Pandit M). Orient Longman

Kamble S (1986) The kaleidoscopic story of my life. Purva Prakashan

Kavka GS (1983) Hobbes's war of all against all. Ethics 93(2):291-310

Keshavamurthy K (2013) P. Sivakami: the caste and gendered body. J Dept English Vidyasagar Univ 11:121-138. 14

Limbale S (2010) Towards an aesthetics of dalit literature: history, controversies, and considerations (trans: Mukherjee A). Orient Black Swan

Lloyd M (1988) A feminist mapping of Foucauldian politics. In: Diamond I, Quinby L (eds) Feminism and Foucault: reflections on resistance. Northeastern University Press

Lukes S (1974) Power: a radical view. Macmillan

MacKinnon C (1987) Feminism unmodified: discourses on life and law. Harvard University Press

Masilamani C, Shanthi L (2017) Bama's Sangati: a voice for voiceless dalit women. Int J Interdiscip Res Arts Humanit 2(1):236-239

Millett K (1970) Sexual politics. University of Illinois

Nayar PK (2011) The politics of form in dalit fiction: Bama's Sangati and Sivakami's The Grip of Change. Indian J Gender Stud 18(3):365-380. https://doi. org/10.1177/097152151101800304

Omvedt G (1994) Dalits and the democratic revolution. SAGE

Pan A (2018) Dalit women in mutation: the birth of a new social organism. Contemp Voice Dalit 10(1):67-76. https://doi.org/10.1177/2455328X17745171

Paswan S (2011) Dalits and practices of untouchability. Neha Publishers \& Distributors

Pawar U (2009) The weave of my life (trans: Pandit M). Columbia University Press Pitkin HF (1972) Wittgenstein and justice: on the significance of Ludwig Wittgenstein for social and political thought. University of California Press

Raj R (2016) Voicing the oppressed: a study on Bama's Sangati Int J English Lang Lit Transl Stud 3(4):243-249. https://www.ijelr.in/3.4.16/243-249\%20RENU \%20RAJ.pdf

Rege SS (2006) Writing caste/writing gender: narrating Dalit women's testimonios. Zubaan

Sangeetha V, Peruvalluthi V (2018) Women marginality in P. Sivakami's the grip of change. Shanlax Int J English 6(2):144-147

Satyanarayana K, Tharu S (2013) The exercise of freedom: an introduction to Dalit writing. Navayana

Sawicki J (1998) Feminism, Foucault and "Subjects" of power and freedom. In: Moss J (ed) The later Foucault: politics and philosophy. Sage Publications

Shyamala G (2012) Father may be an elephant and mother only a small basket, but... Navayana

Sivakami P (2017) Poetics to political transformation-Dalit women writings. In: Awaya T, Suzuki M (eds) FINDAS international conference series 2: literary intervention and political culture in South Asia. The Center for South Asian Studies, Tokyo University of Foreign Studies 
Sivakami P (2006a) The grip of change. Kindle ed, Orient Longman

Sivakami P (2006b) The grip of change. Orient Longman

Soni (2015) Double marginalization of Dalit woman: a study of P. Sivakami's the grip of change. Int J Enhanced Res Manag Comput Appl 4(10):47-49

Spivak GC (1988) Can the subaltern speak? In: Nelson C, Grossberg L (eds) Marxism and the interpretation of culture. University of Illinois Press, pp. 271-313

Vinoliya KA (2018) Subjection of dalit women in Bama's Sangati. Lang India 18 (3):8-11

Wartenberg TE (1990) The forms of power: from domination to transformation. Temple University Press

Wittig M (1993) One is not born a woman. In: Abelove H, Barale AM, Halperin DM (eds) The lesbian and gay studies reader. Routledge, pp. 103-109

Wrong DH (1997) Power: its forms, bases, and uses. Transaction Publishers

\section{Acknowledgements}

For proofreading the paper, I thank Megha Mohanty, Pondicherry University.

\section{Competing interests}

The authors declare no competing interests.

\section{Additional information}

Correspondence and requests for materials should be addressed to A.G.

Reprints and permission information is available at http://www.nature.com/reprints

Publisher's note Springer Nature remains neutral with regard to jurisdictional claims in published maps and institutional affiliations.

\begin{abstract}
(c) (i) Open Access This article is licensed under a Creative Commons Attribution 4.0 International License, which permits use, sharing, adaptation, distribution and reproduction in any medium or format, as long as you give appropriate credit to the original author(s) and the source, provide a link to the Creative Commons license, and indicate if changes were made. The images or other third party material in this article are included in the article's Creative Commons license, unless indicated otherwise in a credit line to the material. If material is not included in the article's Creative Commons license and your intended use is not permitted by statutory regulation or exceeds the permitted use, you will need to obtain permission directly from the copyright holder. To view a copy of this license, visit http://creativecommons.org/ licenses/by/4.0/.
\end{abstract}

(C) The Author(s) 2021 